\title{
Property Issues in Displacement and Conflict Resolution
}

\author{
Tim Wichert
}

\begin{abstract}
Property plays an important role in the decisions made by refugees and displaced persons regarding durable solutions for them and their families. In particular, it will affect their decision whether to return to their homes. Understanding property rights in this context is imperative, especially for agencies involved in post-conflict rehabilitation. This paper sets out the context by outlining various legal and practical considerations. It then looks at specific initiatives in Mozambique, Bosnia and Nicaragua. For a variety of reasons, there is a move towards "non formal" resolution of property disputes, in particular the use of alternative dispute resolution mechanisms. These are considered, and seven points of comment and conclusion then follow.
\end{abstract}

\section{Précis}

La propriété joue un rôle important dans les décisions prises par les réfugiés et les personnes déplacées lorsqu'il s'agit d'établir des solutions durables pour eux-mêmes et leurs familles. Cette question va particulièrement influer sur leur décision quant à une réintégration de leurs foyers. Une compréhension des droits de propriété est, dans un tel contexte, cruciale, surtout pour des agences impliquées dans la reconstruction après un conflit. Le présent article se propose de décrire ce contexte particulier, en résumant un ensemble de considérations légales et pratiques. Il analyse ensuite différentes initiatives particulières au Mozambique, en Bosnie

Tim Wichert is currently with the Mennonite Central Committee's UN Liaison Office in New York. From 1994 to 1997 he worked with the Quaker UN Office in Geneva, and prior to that was with MCC in Nairobi, Kenya. He has a law degree from Queen's University, Kingston, Ontario and has practised refugee law in Toronto. et au Nicaragua. Pour un ensemble de raisons, on remarque une nette orientation en direction d'une résolution "informelle" des contentieux fonciers, et notamment la mise à profit de mécanismes alternatifs de résolution de conflit. Ces derniers sont décrits, et l'exposé se scelle sur sept points de commentaire conclusif.

\section{Introduction}

Property issues at the best of times can be difficult and controversial. They are fraught with cultural, religious and political connotations and variations, that are difficult to universalize. Because of domestic variations and the principle of national sovereignty, there are few guidelines at the international level for resolving property issues. While the right to own property is enshrined in the Universal Declaration of Human Rights, the Cold War era underscored how different political philosophies define this right. Since then, we have begun to better understand the complexity of the property issue in other regions of the world, primarily the impact of traditional and religious rights and imperatives. There are also more voices speaking to issues of nondiscrimination and equality, particularly on the basis of gender.

Beyond the complexity of legal theory, there are the more practical matters of resolving property issues in the context of conflict and displacement. Understanding property rights and finding practical ways to help disaster and war victims deal with them is increasingly becoming an important part of the work of agencies involved in post-conflict rehabilitation. The issue of property plays an important role in the decisions made by refugees and displaced persons regarding durable solutions for them and their families. In particular, it will affect their decision whether to return to their homes. In the long term, the establishment of a clear and secure legal framework for property rights is essential for sustainable development, including investment and economic recovery.

\section{Some Legal Considerations}

\section{International}

The Universal Declaration of Human Rights (1948) states that "Everyone has the right to own property alone as well as in association with others ... [and] ... No one shall be arbitrarily deprived of his property" (Art. 17). However, it proved impossible to reach agreement on including this right in either the International Covenant on Civil and Political Rights, or the Covenant on Economic, Social and Cultural Rights (1966).

A number of other international standards also speak to the property issue. The Women's Convention (i.e., the Convention on the Elimination of all forms of Discrimination against Women, or CEDAW) requires States to ensure the same rights for wife and husband in acquiring, owning, enjoying and disposing of property (Art. 16(1)(h)). The International Labour Organization Convention speaks to the cultures and spiritual values of indigenous and tribal people with respect to land, in particular the collective or communal aspects. Specifically, it requires recognition of ownership and possession rights over land traditionally occupied (No. 169, art. 13-19).

At a regional level, the right to property (i.e., the peaceful enjoyment of possessions) was included in the European Convention on Human Rights, specifically through the First Protocol (1952). However, it specifically preserves the power of the State ("in the public interest") to take certain measures with respect to property. Both the American Convention on Human Rights, and the African Charter on Human and Peoples' Rights also contain the right to property. These are also subject to re- 
striction in the interest of society or the community. Amongst other things, such a restriction allows for nationalization policies.

\section{National}

National sovereignty, embodied in provisions that the right to property is subject to legitimate societal interests, ultimately leads to a range of domestic variations. These variations are governed by domestic legislation that can be based on a variety of underlying political philosophies. Domestic property rights can be vested in the individual, in the state, in the community, and in some cases are also governed by religious imperatives (i.e., Sheria law).

In Kenya, for example, land is subject to a variety of laws, many of which originated during the colonial period. ${ }^{1}$ While there is an explicit policy direction and trend towards the private registration of land, there are also constitutional safeguards for communal land tenure. ${ }^{2}$ This can often lead to legislative confusion, including some specific inconsistencies. Negotiating the legal maze can be further complicated by a lack of resources and a particular political climate (i.e., in which elites aim to protect their own interests).

\section{Universal Principles}

How can international principles inform domestic policies within this context? It is important to underscore and promote universal principles, while realizing that there is also a need to promote certain principles at a national level. The following should be considered:

- clear legal protection for access or ownership, as individuals or as communities;

- restoration to rightful owners, or adequate compensation, particularly after dispossession (by the State or by others);

- within both of these contexts, ensure equality of opportunities and access for vulnerable groups, including women, peasant farmers, pastoralists, etc.

\section{The Context of Displacement}

\section{Practical Considerations}

Displaced people and refugees tend to lose much of their property when forced to flee. Apart from land itself, this can include crops and livestock, homes and shelters, and other personal belongings. Property is often destroyed, confiscated or stolen, particularly so in the context of armed conflict.

Within countries of asylum, these items are provided by the host government or the international community. Access to land is controlled by the host country. The government determines which land is to be used for refugees. The amount of land made available will determine whether there are sufficient opportunities for farming and grazing, and will ultimately affect the degree of self-sufficiency.

Difficulties arise when displaced persons (including refugees) return to their homes and find their property used and occupied by others. Not only is this an obstacle to return in the first instance, but it raises broader issues of reconciliation, and specific issues of restitution. How is the right to property claimed in this context, particularly through restitution or compensation?

The United Nations High Commissioner for Refugees (UNHCR) (1996a) lists access to land as one of the primary constraints to voluntary repatriation. Land is particularly pertinent for returnees from rural and agrarian communities, but has often been taken over by other displaced persons. It is important to know the policies of local and national authorities in this context. For example, the Government might make land available for returnees, either near their original communities or further afield. On the other hand, it might oppose settlement in certain areas for political reasons. In Cambodia, returnees were given a choice between land in a particular location or a cash grant; apparently 95 percent chose cash and then settled with relatives in other areas.
As part of its repatriation programme, the UNHCR develops Quick Impact Projects (QIPS) for providing reintegration assistance within countries of origin. In formulating these, a specific consideration is whether problems of accessibility to peasant farming land will be encountered. Matters to look for include present conditions of land occupancy and ownership policy (UNHCR 1994).

Reintegration is frequently impeded by limited access to land, according to a joint UNHCR and the United Nations Development Program (UNDP) review of the rebuilding process in Central America (UNHCR 1995). The review suggests that UNDP should have a clear understanding about what it can do in this regard, although both agencies obviously have an interest in addressing the problem. Suggested activities include the establishment of a land register system, a system for issuing land titles, and land reform institutes.

These formal systems tend to be underdeveloped in many regions of the world. ${ }^{3}$ During armed conflict, and subsequent reconstruction, domestic legal systems tend to be even more dysfunctional. Whether they should be revitalized or reformed is an important consideration for international agencies. Not only is it a long term process, but it touches on issues of national sovereignty and policy. Courts, and other systems for dispute resolution, are necessary to create an environment that encourages return and deals with potential conflict after return. Apart from official assistance at the national level to rebuild the judicial system, efforts can be made at a local level to create informal or traditional mechanisms that build on local knowledge and experience. These could be particularly useful for assisting with disputes related to land, as well as questions of restitution or compensation.

Another consideration for agencies and NGOs is whether to become involved in acquiring or leasing land on behalf of displaced persons. This could provide a short-term solution when restitution or compensation is not im-

Refuge, Vol. 16, No. 6 (December 1997) 
mediately forthcoming (i.e., subject to dispute), or when the Government is not facilitating access to land.

\section{Legal Considerations}

International legal instruments provide some protection in situations of armed conflict. When they are internal, Protocol II of the Geneva Conventions (1949) protects personal property of displaced persons from theft and vandalism, and prohibits the destruction and removal of "indispensable" matters such as food, crops, livestock, and drinking water. When the conflicts are between States, certain provisions in the Geneva Conventions and the Hague Regulations (1907) apply. For example, they provide protection for dwellings or buildings which are undefended, they prohibit destruction of property (real and personal), and prohibit the confiscation of private property. On the other hand, property can be "requisitioned" for the needs of the occupying force, and exceptions are allowed for "military necessity" (Deng 1995, 276-78).

There is increasing recognition of the right to restitution at the international level. The rules of the War Crimes Tribunal for the former Yugoslavia allow for the award of restitution of property, or its proceeds, to victims (Art. 105). The Inter-American Commission on Human Rights has recommended that compensation be given to returning IDPs for loss of property, including homes, crops, and livestock. The World Bank suggests there should be full compensation for people involuntarily displaced as a result of development projects that give rise to "severe" economic, social and environmental problems (Operational Directive on Involuntary Resettlement).

Most importantly, the domestic laws of States affected by displacement need to be examined on an individual basis to determine the extent of property protection. Specifically, they might address the right to property, and the issue of restitution or compensation.

\section{Case Studies}

\section{Mozambique}

Land has long been a source of conflict in Mozambique, and its relation to returning refugees was highlighted in a recent report by the Lawyers Committee for Human Rights (1995). Both the liberation struggle with Portugal and the more recent civil war have been struggles over differing concepts of land ownership and control (the former in a colonial context and the latter in a socialist context). In the recent and current context of repatriation, access to land is a crucial issue since the vast majority of refugees and displaced were peasant farmers.

The General Peace Agreement included provisions that guaranteed restitution of property which was owned and still in existence, as well as the right to take legal action to secure the return of property. However, since land in Mozambique is vested in the state, this does not practically apply to land (the state assigns "use" to individuals).

More importantly, the Memorandum of Understanding between the Government and UNHCR stated that, "The Government shall ensure that returnees have access to land for settlement and use, in accordance with Mozambique law." How are such provisions ultimately implemented? Disputes are inevitable, particularly where land is most fertile, where infrastructure is most developed and has been repaired, and near borders where there has been a regular flow of people. (On the other hand, the people of Mozambique are all too familiar with displacement, through the liberation and civil wars, as well as drought and famine. Lessons could probably be learned from past experience with settling disputes in the context of displacement.)

The problem in Mozambique, as in most countries which had a colonial history, is that the notion of traditional authorities is complex. The colonial powers imposed one type of system, the independence government another, with opposition groups during a conflict perhaps installing yet an- other within areas of their control. In other situations, communities might have maintained more traditional systems based on bloodline chiefs. A policy of simply reinstating traditional authorities can prove difficult. It may be necessary to rely on new forms of authority, including those that may have been developed by communities while in the country of asylum, or while displaced within their own country.

Specific problems that have been encountered in Mozambique include the assignment of land titles to foreign interests, including multinational companies and ex-colonists. Land allocated in this manner is sometimes that which had been abandoned by displaced people. In other cases, returning refugees and others have not always known about legal procedures and how to pursue their claims. Some have faced bureaucratic obstruction. In effect, obstacles which may already exist in many countries are merely exacerbated in the context of displacement.

\section{Bosnia}

Bosnia and the former Yugoslavia offer a good example of post-conflict challenges related to property. The international community, through the Office of the High Representative pursuant to the Dayton Peace Agreement, has created the Commission for Real Property Claims of Displaced Persons and Refugees. At the national level, there is legislation which exists and is being interpreted by the courts. Also at the national (or community) level, there are other informal processes at work.

\section{The Property Commission}

The Property Commission started on 20 March, 1996. It has nine members: three appointed by the European Court of Human Rights, four by the Federation of Bosnia and Herzegovina and two appointed by the Republika Srpska. It is meant to adjudicate claims for return of property or compensation for dispossession. Annex 7 of the Dayton Agreement gives the Commis- 
sion power to "promulgate such rules and regulations ... as may be necessary to carry out its functions." In doing so, it is required to consider domesticlaws on property rights. Initially, much faith seems to have been placed in the Commission, and its basic aim was meant to be confidence building. Over 20,000 claims have been filed with the Commission since it was created.

However, reports indicate that their decisions have been delayed by a number of factors. They have been chronically underfunded, and suggest that their funds will run out in June this year (they have reported that they need $\$ 6$ million to function through 1997). One practical effect of this has been the inability to obtain specially treated and prepared paper for issuing written certificates in order to avoid counterfeiting. Further, the Commission has been accused of avoiding politically sensitive issues concerning tenancy rights, evictions, and war time legislation, and has proven unwilling to stand up to existing authorities (Forced Migrations Projects 1997a, 1997b). In short, it has been a disappointment.

\section{The Judicial Process}

Thejudicial process appears to be functioning in many parts of Bosnia, albeit in a limited way. Problems, which have arisen, relate to the nature of existing legislation, the independence of the judiciary, and the lack of enforcement of court orders.

Existing legislation is problematic in a number of ways. Firstly, there is some inconsistency between different legal enactments. Secondly, there were some that were enacted during the conflict, and now create discriminatory obstacles to return (i.e. original rights have been lost, sometimes being superseded by temporary rights). Finally, there is some relevant legislation and documentation that is unknown and difficult to ascertain (Forced Migration Projects 1996a).

Regarding independence of the judiciary, there have been some concerns expressed about the lack of transparency in the selection process for judges by the Sarajevo Cantonal Assembly. In a recent decision, fourteen of 37 Cantonal Courtjudges were not re-elected, and fifteen of 41 municipal judges were not reappointed. Apparently no explanation or advance notice was given and all apparently had substantial professional experience (Office of the High Representative [OHR] 1997).

Even when favourable court rulings are obtained, they are not being obeyed. Following the expulsions of Muslims and Croats from Banja Luka in 1995 (ostensibly to accommodate the influx of Serb refugees expelled from Krajina) most of the evicted filed claims in local courts. Approximately forty have won their cases. However, local police have ignored court decisions, even when ordered repeatedly to execute them. The OHR (Human Rights Coordination Office) reported that none of the 25 reinstatements scheduled for April went ahead. They blamed the lack of action on the failure of local police to show up at the properties and enforce court orders (Forced Migration Projects 1997c). Evictions continue to take place all over Bosnia, by all three ethnic groups.

The positive aspect of this is the fact that some people have been able to access the courts to obtain favourable rulings relating to their property.

\section{Other Processes}

There are a number of initiatives which can potentially have a "political" impact. These include the Office of the High Representative (who has created a Sub-Committee on Property), the Ombudsman of the Federation of Bosnia and Herzegovina, the FMP's Legal Policy Task Force, which is made up of lawyers from the region and international experts, etc. These have the potential for taking up matters at a political level, such as applying direct pressure on Bosnian politicians. However, this kind of advocacy is obviously ad hoc and time-consuming.

Other efforts might consist of legal education and legal assistance for court actions. Both of these are limited by the fact noted above that people have actually been able to access the courts to obtain rulings. The problem rather has been one of enforcement. Because of this, more efforts could be put into mobilizing civil action for enforcing court orders, or acquiring/ buying property for redistribution.

\section{Nicaragua}

The case of Nicaragua is obviously different from that of Bosnia, the former being a conflict largely of ideology and the latter largely one of ethnicity. Nonetheless, there are parallels.

\section{The Follow-up Commission}

In 1995, five years after the Chamorro government was elected to replace the Sandinistas, property was still a much disputed topic. In July 1995, a two-day conference sponsored by the UNDP and the Carter Center brought together participants from all sides of the issue in what proved to be an atmosphere of respect and constructive problem-solving. The conference brought together over seventy people representing the cabinet, the National Assembly, leaders of the major political parties, members of the Supreme Court, leaders of organizations representing former property owners, present occupants, workers, ex-combatants, and some outside observers (i.e., diplomats, international financial institutions). The key issues related to effective compensation and follow-up. Regarding the former, options agreed to included the proposed sale of at least 40 percent of the Nicaraguan telephone company to raise part of the necessary funds, along with other initiatives such as lotteries and international assistance. Regarding the latter, a Follow-up Commission was created involving government, legislative and civil society representatives (which were to complete their work within 3 months).

\section{The Judicial Process}

Part of the discussion process was to agree to the need for 5 new courts, 2 within the capital Managua and 3 outside, to deal with the thousands of cases expected to go to litigation (UNDP has provided funding for these 
courts). Other suggestions included the appointment and training of quasijudicial officers (law clerks, lawyers) to facilitate case processing, thus freeing the judges to actually make decisions.

There has been some disagreement over the need for new legislation. As with Bosnia, much helpful legislation existed, although there was a need to deal with contradictory and discriminatory legislation. It was easier to obtain agreement on legislation relating to small holdings, especially as part of an overall policy of agrarian and urban reform. It has not been as easy to obtain agreement over larger properties and houses, and the amount and form of compensation.

\section{Other Processes}

A 1995 Report prepared for the UNDP by the Carter Center recommended a 2-track approach for resolving property disputes and stimulating the longterm growth of peaceful dispute resolution in Nicaraguan society (Carter Center 1995a). First, they recommended an Ombudsman's Office for handling complaints. In particular, they would provide information to claimants (of property rights), assist them through the maze of administrative offices, and refer some cases to mediation services. This purpose would be to reduce the burden on the courts and produce faster resolution of cases.

Secondly, the Report recommended the development of an "independent, non-profit non-governmental organization" dedicated to conflict resolution. Such an NGO would develop a panel of mediators as well as staff to monitor court dockets and encourage people to use mediation. Judges would also be able to refer cases to mediation. The purpose would be 3-fold: reduce the work of the courts and speed up resolution in the short-term; provide training to mediation groups in the medium-term; and provide $\mathrm{a}$ basis for alternative dispute resolution mechanisms in the long-term.

In order to ensure both impartiality and training (and avoid politicization) there would need to be collaboration between established and respected institutions. In the short-term, mediation efforts by existing groups could be encouraged and supported with training.

Although there has been some difficulty in following through with these recommendations, the current government is apparently trying to revive and restructure the concept of a mediation centre, with the assistance of the UNDP.

\section{Alternative Dispute Resolution (ADR)}

For a variety of reasons, both legal and practical, many people would likely settle for a "non-formal" resolution to disputes relating to property. For example, there seems to be a growing informal market in property and land in many post conflict settings, especially when the formal system does not meet expectation. There is clearly a trend in many Western countries to develop alternative systems for dispute resolution in industrial, labour, family and other legal fields. In determining the appropriateness of ADR models for situations of conflict or post conflict, there are a number of considerations.

- Are there components of society which support ADR? This is important for ensuring that there is a motivation to use it, because it is perceived to be an effective alternative. Amongst other things, the society must be willing to use consensual approaches to dispute resolution and perceive them to be impartial.

- Are there laws which require or allow ADR? These laws will ensure that decisions reached can be supported and enforced if necessary. For example, laws regarding arbitration usually allow courts to enforce decisions that are made. On the other hand, is it appropriate to provide a legislative framework for such a system, or allow informal systems to develop on a voluntary basis.
- Are there existing efforts, and is there existing capacity, to develop $A D R$ ? In particular, there must be a knowledge of the process, and a capacity for training. Training models may be brought in from outside, or they may be based on traditional models, or they may need to be a combination of models. There must be broad based conflict management training.

\section{Comments}

a) The property issue must be placed within the broader context of sustainable development. Resolving disputes will be necessary to ensure the requisite stability for economic recovery and investment. For many people, land is the "means of production," and the rebuilding and continued development of a society is dependant on people accessing and using it.

b) There is an urgency to resolving property disputes, in that they remain an ongoing source of potential conflict. At the same time, creating the necessary consensus and institutions takes time.

c) Although there are clear gaps within the legal systems of many countries, and laws are often vague, unclear, contradictory or discriminatory, the main property problem is one of enforcement. This is especially important, for example, when international peace agreements turn over dispute settlement to the "application of domestic legislation." Such legislation is only as effective as the ability to enforce it.

d) Legal education must take place concurrently with the rebuilding of judicial institutions. Making people aware of their legal rights implies that there must be effective legal institutions to which they can turn to for assistance.

e) Alternative dispute resolution mechanisms must be created-either new ones, or based on traditional mediation. People will often create informal property markets when the formal structures do not appear to work. 
f) Compensation must be a primary consideration, given that many people will not be able to get their land back (it is impossible to restore things to their previous state). The nature and amount of compensation must be dealt with.

g) Agencies must give more consideration to what processes they can be involved in.

\section{Notes}

1. Apart from the Constitution itself there are the following statutes: Registered Land Act, Land Titles Act, Government Lands Act, Registration of Titles Act, Registration of Documents Act, Land Control Act, Land Consolidation Act, Land Adjudication Act, Land (Group Representatives) Act.

2. See generally, Lenaola, Jenner and Wichert, "Land tenure in pastoral lands," in In Land We Trust: Environment, Private Property and Constitutional Change, edited by Juma and Ojwang (Initiatives Publish- ers, Nairobi and Zed Books, London, 1996).

3. Including a lack of effective administrative machinery for implementing existing legal statutes.

\section{References}

Carter Center. 1995a. "Nicaraguan Property Disputes." Report prepared for UNDP, 15 March.

_. 1995b. "Report on a Property Issues Conference, Montelimar, Nicaragua, July 3-4."

Deng, Francis. 1995. "Internally Displaced Persons: Compilation and Analysis of Legal Norms." Report of the Representative of the Secretary-General on IDPs, UN Doc. No. E/CN.4/1996/52/Add.25, December.

Forced Migrations Projects (FMP). 1996a (March). "Property Law in Bosnia and Herzegovina." New York: Open Society Institute.

_. 1996b (April). “Compilation of Selected Property Laws Concerning Bosnia and
Herzegovina." New York: Open Society Institute.

—. 1996c. Monitor No. 11, May. New York: Open Society Institute.

—. 1997a. Monitor No. 15, January. New York: Open Society Institute.

- 1997b. Alert No. 25, 21 April. New York: Open Society Institute.

_.1997c. Alert No. 26, 28 April. New York: Open Society Institute.

Lawyers Committee for Human Rights. 1995 (July). "African Exodus: Refugee Crisis, Human Rights and the 1969 OAU Convention."

Office of the High Representative (OHR). 1997. Weekly Human Rights Update, 21-27 April.

UNHCR. 1994 (June). Policy and Methodological Framework for QIPS: Guidelines.

- 1995 (May). CIREFCA: An Opportunity and Challenge for Inter-Agency Cooperation.

- 1996a. Voluntary Repatriation Handbook: International Protection. Geneva:UNHCR.

- 1996b (November/December). General Repatriation Information Report for Bosnia and Herzegovina. Geneva: UNHCR. a

\title{
From Being Uprooted to Surviving: Resettlement of Vietnamese-Chinese "Boat People" in Montreal, 1980-1990
}

\author{
By Lawrence Lam
}

Toronto: York Lanes Press; ISBN 1-55014-296-8, 200 pages, indexed; \$18.95

Thesaga of the 4 bot people" is a dramaticstory, a story of one of the largest refuge movements in recenty years: Canada played a significant role in the resettlement of these refugees in bringing them to Canada where they could start anew. From Being Uprooted to Surviving by Professor Lam, is based on ethnographic data of a sample of Vietnamese-Chinese accepted for resettlement in Montreal in 1979 and 1980 , who were intervieved again in $1984-85$ and in 1990-91, this book provides a longitudinal account of their experience of resettlement in Canada. This experience has been marked by successivestages of their struggle to overcome structural barriers and to negotiate a meaningrul riche in Canada.

Contents, Preface, The Boat People Phenomenon, Resettlement-Issues and Perspectives, The VietnameseChinese Refugees, Exodus and Transition, Resettlement Process. The Rirst Mriree Years, Resettlement Beyond the First Three Years, Conclusion.

Plense send your orders 10:

gentre tor, Rerrigee Studles. York University

Suite 336 . Yonk Lanes, 4700 Keele Street

Toronto ON Camada MBJ IPS

Fax. (416) 736-5837 - Emall refuge@y on ku.ca 